\title{
Effect of changes in live body weight and feed conversion ratio as influenced by enzyme supplements on basic post-slaughter measurements of broiler chickens fed cereal-based diets
}

\author{
W. Szczurek and J. Koreleski \\ Research Institute of Animal Production, \\ Department of Animal Nutrition \\ 32-083 Balice, Poland
}

(Received 29 April 2002; accepted 11 October 2002)

\begin{abstract}
The present work was designed to clarify the relationship between carcass yield (CY) and abdominal fat $(\mathrm{AF})$ percentages with changes in final live body weight (LBW) and feed conversion ratio (FCR) in broilers as caused by supplementary feed enzymes. The experimental data set was obtained from a total of eleven growth trials carried out with chickens of currently used commercial strains. In all of the trials the chickens were fed ad libitum with mash diets based on home-grown cereals and soyabean meal, and containing fat additions, mainly as animal blended fat. Different commercial enzyme preparations were added to the diets either alone or in combination. The mean responses to enzymes were $+86 \mathrm{~g}$ for final LBW, $-0.08 \mathrm{~g} / \mathrm{g}$ for FCR, $+0.031 \%$ for $\mathrm{CY}$ and $+0.024 \%$ for AF. For main (Pearson) correlation assessments and (linear) regression analysis, the observed values obtained with birds fed enzyme preparations were expressed relative to the data of control birds fed unsupplemented diets $(=1.00)$. No correlation could be established between enzyme-caused relative changes in: LBW and CY, FCR and $\mathrm{CY}$, and FCR and AF. A highly significant positive correlation was found between relative changes in final LBW of chickens and relative percentage of $\mathrm{AF}$. For this relationship the regression equation was: $Y_{\triangle F}=-2.882+3.735 X_{L B W},\left(R^{2}=0.529, P \leq 0.001\right)$. It was concluded that augmented abdominal fat accumulation in broilers fed enzyme preparations can be avoided by lowering the quantity of animal fat added to the cereal diets to meet the energy needs of the chickens.
\end{abstract}

KEY WORDS: broiler chickens, feed enzymes, performance, post-slaughter measurements, correlations

\section{INTRODUCTION}

The application of NSP-degrading enzyme preparations in broiler diets, especially with high proportions of cereals, has become common practice during 
the last decade. These preparations are used to diminish the antinutritive effects of viscous, soluble non-starch polysaccharides in wheat, barley, rye or triticale and thus to increase dietary nutrient utilization, energy metabolizability and bird performance (Brufau et al., 2001). Use of exogenous enzymes in diets containing cereals that do not cause viscosity problems (maize, sorghum) may accelerate starch digestion in the small intestine and increase the performance of birds (Bedford, 2000). The utilization of exogenous proteases or blends of NSP-degrading and proteolytic enzymes is beneficial to improving the performance value of diets based on such vegetable protein sources as seeds of legumes, soyabean meal and rape seed products (Brenes et al., 1993; Simbaya et al., 1996; Pack et al., 1997).

The main criterion for enzyme efficacy in broiler nutrition are changes in growth performance indices (Rosen, 2000). As food quality, especially augmented fat content, is an important health concern for consumers, the quality of broiler carcasses has become of greater interest (Lippens, 2001). However, there is relatively less information about the effects of different enzyme additives on carcass quality attributes and slaughter value of broiler chickens. This inspired us to make an attempt to find out how and to what extent some post-slaughter measurements are linked with basic performance characteristics in broilers fed enzyme-supplemented cereal diets. Based on experimental data collected from different growth trials performed in our laboratory, the objective of this work was to examine the relationships of carcass yield and abdominal fat percentages with changes in final live body weight and feed conversion of broilers as caused by supplementary feed enzymes.

\section{MATERIAL AND METHODS}

The data set analysed in the current work was obtained in eleven independent trials carried out in 1996-2002. The experimental results have been reported in part in original papers (Szczurek and Koreleski, 1998, 1999; Koreleski et al., 2000; Szczurek et al., 2000b).

\section{Design of trials and diets}

In all trials, day-old unsexed broiler chickens of different commercial strains were used. Birds were randomly allocated either to floor pens with wheat straw as litter (trials 1 to 7) or battery cages with a wire floor (trials 8 to 11). All birds were kept in temperature- and ventilation-controlled broiler houses with continuous light. Different numbers of replicates and birds per replicate (pen) were used in the floor trials. In the battery trials experimental groups consisted of five replicates (cages) of 8 or 10 birds each. The details of the trial layout are provided in Table 1 . 
TABLE I

Design of trials

\begin{tabular}{ccccccc}
\hline $\begin{array}{c}\text { Trial } \\
\text { no. }\end{array}$ & $\begin{array}{c}\text { Broiler } \\
\text { strain }\end{array}$ & $\begin{array}{c}\text { Rearing } \\
\text { systen }\end{array}$ & $\begin{array}{c}\text { Birds } \\
\text { per group }\end{array}$ & $\begin{array}{c}\text { Number } \\
\text { of replicates } \\
\text { per group }\end{array}$ & $\begin{array}{c}\text { Birds } \\
\text { per replicate }\end{array}$ & $\begin{array}{c}\text { Birds } \\
\text { slaughtered } \\
\text { per group }\end{array}$ \\
\hline 1 & Starbro & $\begin{array}{c}\text { floor pens } \\
\text { (straw litter) }\end{array}$ & 800 & 4 & 200 & 8 \\
2 & Ross & as above & 270 & 3 & 90 & 8 \\
3 & Ross & as above & 270 & 3 & 90 & 8 \\
4 & ISA & as above & 480 & 6 & 80 & 8 \\
5 & Hubbard & as above & 320 & 4 & 80 & 8 \\
6 & Starbro & as above & 1278 & 6 & 213 & 10 \\
7 & Arbor-Acres & as above & 210 & 3 & 70 & 8 \\
8 & Hubbard & battery cages & 40 & 5 & 8 & 8 \\
9 & Hubbard & as above & 40 & 5 & 8 & 8 \\
10 & Avian & as above & 50 & 5 & 10 & 8 \\
11 & Avian & as above & 50 & 5 & 10 & 8 \\
\hline
\end{tabular}

In both rearing systems applied, all chickens were provided with feed in mash form and water for ad libitum intake. The starter diets were fed from days 1 to 21 . From 22 to 35 days of age the chickens received grower diets. The finisher diets were fed from days 36 to 42 (in trials 7 and 10 to 48 and 45 days. respectively). All diets were based on wheat and barley, and soyabean meal as the major source of vegetable protein (Table 2). Fat additions to the diets were provided as animal blended fat, with the exeeption of trial 6 in which soyabean oil was used. Coccidiostats and growth promoters were introduced into all starter and grower diets. The metabolizable energy content of the diets was calculated according to the determined chemical composition of raw feedstuffs, employing equations given in the European Table (1989). Crude protein, essential amino acids and all the other nutrients were supplied in amounts similar to those proposed in the Poultry Feeding Standards (1996).

Ten commercial enzyme preparations obtained from a number of different manufacturers were added to the diets. An enzyme premix A was reported to contain a blend of enzymes produced by submerged fermentation of Bacillus subtilis and Trichoderma reesei. Xylanase premix B contained endoxylanase from Aspergillis orvzae. Commercial carbohydrase preparations $\mathrm{C}, \mathrm{D}, \mathrm{E}$ and $\mathrm{F}$ were reported as multi-activity complexes of cell-wall (NSP) degrading enzymes. Two mixed ( $\mathrm{G}$ and I) and two protcolytic enzyme preparations, containing bacterial endoproteinases from Bacillus licheniformis ( $\mathrm{H}$ and $\mathrm{J}$ ) were also used. The preparations were added to the basal diets either individually, with single or graded levels of inclusion, or in combination, at the expense of wheat or barley. The rates of inclusion are presented in Table 2. Enzyme activities as declared by suppliers are shown in Table 3. 


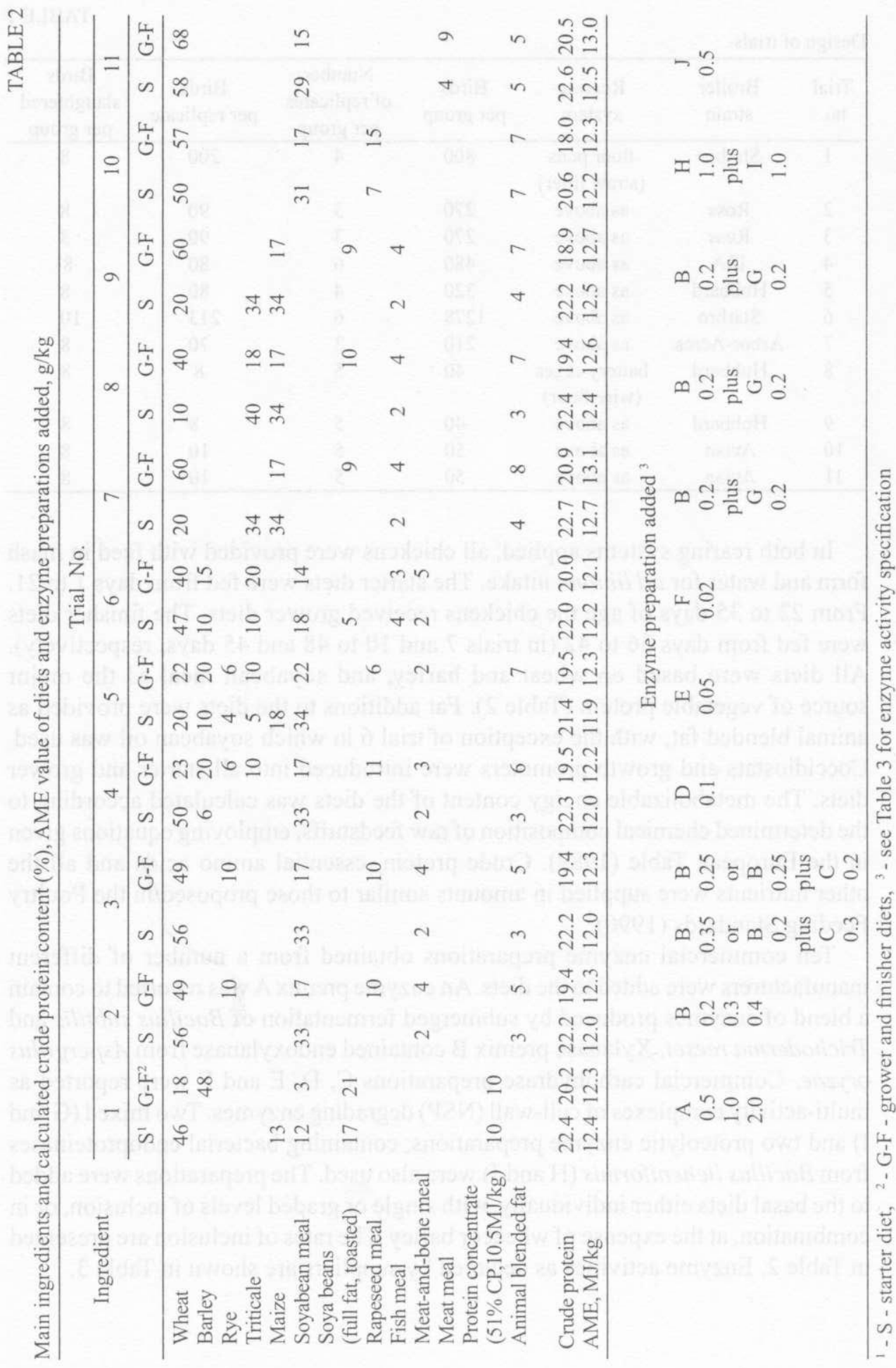


Commercial enzyme preparations used in trials

\begin{tabular}{cc}
\hline Preparation & Enzyme activities per gram of crude product \\
\hline A & 100 amylase units, 2 protease units, $100 \beta$-glucanase units, \\
B & 600 fungal endoxylanase units \\
C & $50 \beta$-glucanase units, 200 endoglucanase units, 120 hemicellulase \\
D & units, 5000 pectinase units \\
E & 8250 xylanase units, $6000 \beta$-glucanase units \\
F & 1400 xylanase units, $2000 \beta$-glucanase units \\
G & $140000 \beta$-glucanase units, 28000 xylanase units \\
H & $220 \beta$-glucanase units, $200 \alpha$-amylase units \\
I & 1.5 endoprotcinase $\Lambda$ nson units \\
J & $100 \beta$-glucanase units, 2500 xylanase units. 800 protease units \\
\hline
\end{tabular}

\section{Measurements}

In all trials the birds were weighed at the start and at the end of rearing, and their feed intake was recorded for the starter and the grower-finisher rearing phases. These data were used to calculate the feed conversion ratio ( $\mathrm{g}$ feed per $\mathrm{g}$ of body weight gain). In the battery trials and in the floor trials, 2, 3, 4, 5 and 7, the chickens were weighed by replicate (cage or pen). In the floor trials 1 and 6, fifty randomly selected birds per pen were weighed.

Post-slaughter measurements were conducted as follows. At the end of each trial 8 or 10 birds of mixed sex (50\% cocks and $50 \%$ pullets) within each group that were close to the mean body weight of that group were chosen. The birds were fasted overnight, weighed the following morning and killed by decapitation, scalded, plucked and manually eviscerated. The carcasses were chilled at $4^{\circ} \mathrm{C}$ for $12 \mathrm{~h}$ and weighed. Abdominal fat including fat surrounding the gizzard was removed and weighed. Carcass yield, including weight of edible giblets (gizzard, liver, heart), was calculated relative to the live body weight and abdominal fat deposition relative to the carcass weight.

\section{Statistical analysis}

Statistical analyses were carricd out with the STATISTICA 5.1 software package. The relationship between post-slaughter measurements and changes in chickens' final body weight and feed conversion ratio as the independent variable, as well as the interrelationship of the performance indices and the measured carcass parameters, were determined by corrclation analysis in which Pearson correlation coefficients were obtained. In addition, when statistically significant correlations were found $(\mathrm{P} \leq 0.05)$, the response variable was regressed against the performance 
TABLE 4 Mean values of final live body weight of broiler chickens, feed conversion ratio ( $\mathrm{g}$ feed/g BWG), carcass yield (\% BW) and content of abdominal fat in carcass (data combined for sexes)

\begin{tabular}{|c|c|c|c|c|c|}
\hline $\begin{array}{l}\text { Trial } \\
\text { no. }\end{array}$ & $\begin{array}{l}\text { Enzyme } \\
\text { inclusion' }\end{array}$ & $\begin{array}{c}\text { Final } \\
\text { weight, } g\end{array}$ & $\begin{array}{c}\text { Feed conversion } \\
\text { ratio }\end{array}$ & $\begin{array}{l}\text { Carcass } \\
\text { yield, } \%\end{array}$ & $\begin{array}{c}\text { Abdominal fat } \\
\% \text { of carcass weight }\end{array}$ \\
\hline 1 & $\begin{array}{l}- \\
+ \\
+ \\
+\end{array}$ & $\begin{array}{l}1605 \\
1660 \\
1652 \\
1647\end{array}$ & $\begin{array}{l}2.23 \\
2.18 \\
2.12 \\
2.16\end{array}$ & $\begin{array}{l}74.6 \\
72.3 \\
75.1 \\
75.3\end{array}$ & $\begin{array}{l}2.10 \\
1.70 \\
1.60 \\
2.00\end{array}$ \\
\hline 2 & $\begin{array}{l}- \\
+ \\
+ \\
+\end{array}$ & $\begin{array}{l}1882^{\mathrm{a}} \\
2025^{\mathrm{b}} \\
2044^{\mathrm{b}} \\
2033^{\mathrm{b}}\end{array}$ & $\begin{array}{l}2.36^{\mathrm{a}} \\
2.19^{\mathrm{b}} \\
2.16^{\mathrm{b}} \\
2.19^{\mathrm{b}}\end{array}$ & $\begin{array}{l}73.7 \\
72.0 \\
72.7 \\
72.3\end{array}$ & $\begin{array}{l}1.92 \\
2.21 \\
2.37 \\
2.03\end{array}$ \\
\hline 3 & $\begin{array}{l}- \\
+ \\
+\end{array}$ & $\begin{array}{l}1813^{a} \\
1885^{b} \\
1903^{b}\end{array}$ & $\begin{array}{l}2.14 \\
2.01 \\
2.05\end{array}$ & $\begin{array}{l}73.4 \\
74.0 \\
73.5\end{array}$ & $\begin{array}{l}2.54 \\
2.62 \\
2.16\end{array}$ \\
\hline 4 & - & $\begin{array}{l}1947 \\
2007\end{array}$ & $\begin{array}{l}2.13^{\mathrm{a}} \\
2.04^{\mathrm{b}}\end{array}$ & $\begin{array}{l}72.4^{\mathrm{a}} \\
74.5^{\mathrm{b}}\end{array}$ & $\begin{array}{l}1.91 \\
1.85\end{array}$ \\
\hline 5 & - & $\begin{array}{l}1819^{a} \\
1898^{b}\end{array}$ & $\begin{array}{l}2.12 \\
2.04\end{array}$ & $\begin{array}{l}73.0 \\
74.9\end{array}$ & $\begin{array}{l}2.05 \\
2.37\end{array}$ \\
\hline 6 & + & $\begin{array}{l}1907^{\mathrm{a}} \\
2003^{\mathrm{b}}\end{array}$ & $\begin{array}{l}2.04^{a} \\
1.98^{b}\end{array}$ & $\begin{array}{l}75.8 \\
75.7\end{array}$ & $\begin{array}{l}2.60 \\
2.80\end{array}$ \\
\hline 7 & - & $\begin{array}{l}2470 \\
2502\end{array}$ & $\begin{array}{l}2.24 \\
2.16\end{array}$ & $\begin{array}{l}73.3 \\
72.8\end{array}$ & $\begin{array}{l}3.07 \\
2.92\end{array}$ \\
\hline 8 & + & $\begin{array}{l}1583^{\mathrm{a}} \\
1771^{\mathrm{b}}\end{array}$ & $\begin{array}{l}2.16^{\mathrm{a}} \\
2.09^{\mathrm{b}}\end{array}$ & $\begin{array}{l}71.8 \\
72.0\end{array}$ & $\begin{array}{l}1.85^{\mathrm{a}} \\
2.55^{\mathrm{b}}\end{array}$ \\
\hline 9 & $\begin{array}{l}- \\
+\end{array}$ & $\begin{array}{l}1483^{a} \\
1576^{b}\end{array}$ & $\begin{array}{l}2.24 \\
2.17\end{array}$ & $\begin{array}{l}69.2^{\mathrm{a}} \\
71.5^{\mathrm{b}}\end{array}$ & $\begin{array}{l}2.47 \\
2.79\end{array}$ \\
\hline 10 & + & $\begin{array}{l}2045 \\
2095\end{array}$ & $\begin{array}{l}2.22 \\
2.39\end{array}$ & $\begin{array}{l}75.9 \\
75.5\end{array}$ & $\begin{array}{l}3.10 \\
2.60\end{array}$ \\
\hline 11 & $\mathrm{EM}^{+}$ & $\begin{array}{l}1693 \\
1709 \\
47.28 \\
\end{array}$ & $\begin{array}{l}2.37 \\
2.29 \\
0.02 \\
\end{array}$ & $\begin{array}{l}75.2 \\
74.7 \\
0.31 \\
\end{array}$ & $\begin{array}{l}2.90 \\
2.90 \\
0.08 \\
\end{array}$ \\
\hline
\end{tabular}

1 - according to Table 3

a,b - within a trial, values with different superscripts differ significantly at $\mathrm{P} \leq 0.05$

data to obtain linear regression equations, according to the model: $\mathrm{Y}=\mathrm{a}+\mathrm{bX}$. For main correlation assessments and regression analysis, the results of measurements were converted to relative values. Values obtained with birds fed enzyme preparations were expressed relative to the data of control birds fed the unsupplemented diet $(=1.00)$. Separately for each trial Duncan's multiple range test at $\mathrm{P} \leq 0.05$ was used to estimate the significance of differences between means presented in Table 4 . 


\section{RESULTS}

All enzyme supplements had a positive effect on chickens' final live body weight (LBW) giving statistically significant or only numerical improvements (Table 4). The significant increases in LBW were established in six trials with mean response of $+119 \mathrm{~g}$. Enzyme supplementation significantly improved feed conversion ratio (FCR) in four trials with a mean response of $-0.12 \mathrm{~g} / \mathrm{g}$. Overall $(n=16)$, as compared with the control birds fed unsupplemented diets, the mean increment of LBW and turn in FCR due to enzyme addition was $+86 \mathrm{~g}(\mathrm{SD}=50.5)$ and $-0.08 \mathrm{~g} / \mathrm{g}(\mathrm{SD}=0.052)$, respectively. The influence of supplementary enzymes on percentage carcass yield (CY) was highly inconsistent, with a mean effect of +0.031 and changes ranging from $-2.3(\mathrm{P}>0.05)$ to $+2.3(\mathrm{P} \leq 0.05)$ percentage units. Enzyme-influenced changes in abdominal fat percentage (AF) varied from -0.50 $(\mathrm{P}>0.05)$ to $+0.70(\mathrm{P} \leq 0.05)$ percentage units. The mean response to enzymes in this parameter averaged $+0.024 \%(\mathrm{SD}=0.35)$.

There were no significant relationships between indices of broiler performance and post-slaughter parameters, nor between these characteristics themselves, when correlation matrix covering values obtained in control birds were processed. In order to estimate correlation relationships of changes in $\mathrm{CY}$ and $\mathrm{AF}$ percentages with shifts in final LBW of broilers and their FCR due to enzyme addition, correlation matrices of relative values ( $17 \times 17$, not shown) were prepared. No significant correlation could be established between enzyme-caused relative changes in LBW and CY $(\mathrm{r}=-0.08)$, FCR and CY $(\mathrm{r}=-0.02)$ and FCR and AF $(r=-0.35)$. There was also no

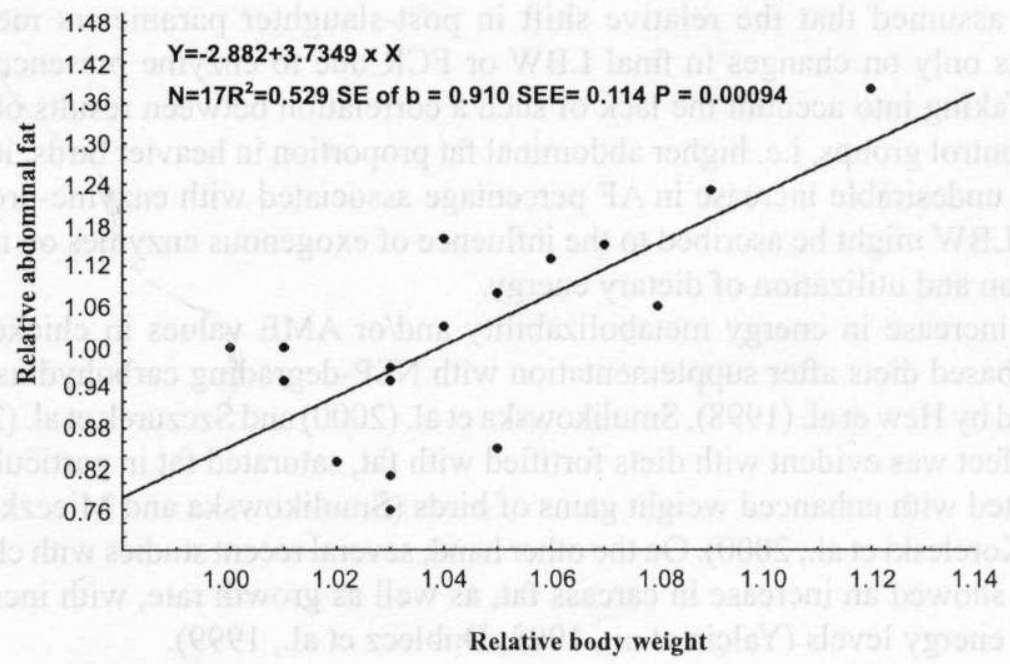

Figure 1. Relationship between relative final live body weight and relative abdominal fat percentage in chickens fed supplementary enzymes (control $=1.00)$ 
correlation between relative changes in post-slaughter measurements $(\mathrm{r}=0.14)$. A highly significant positive correlation was found between relative changes in final LBW and percentage of AF $(0.74 ; \mathrm{P} \leq 0.001)$. For this relationship the regression curve and statistical parameters of the regression equation are given in Figure 1.

\section{DISCUSSION}

Beside their impact on growth performance, the three major groups of factors: genetics, management and nutrition, have been shown to influence carcass yield and abdominal fat deposition in broiler chickens. Genotype-associated changes in quantity of abdominal fat and carcass yield of chickens were recently found by Smith and Pesti (1998) with crosses of high-yielding and fast-growing broiler strains. The influence of dietary (energy and protein levels, fat and amino acid content or source) and environmental factors (feed restriction, temperature and lighting schedules, stocking densities) has lately been reviewed by Lippens (2001) who underlined that controlling broiler carcass composition by feed manipulation is probably more effective than by management tools. However, because many variables are involved, and conflicting results are reported, it is difficult to fully explain how dictary factors affect lipogenesis and fat accumulation in broilers. Lippens (2001) concluded that an increased carcass fat proportion is observed in chickens fed high-energy dicts, especially with added fat, or in birds receiving low protein feeds.

The correlation relationships studied in this work were determined independently of the possible effects of dictary formulations, bird genotype, and rearing method. It was assumed that the relative shift in post-slaughter parameters measured depends only on changes in final LBW or FCR due to enzyme presence in the diets. Taking into account the lack of such a correlation between results obtained from control groups, i.c. higher abdominal fat proportion in heavier birds, it seems that an undesirable increase in AF percentage associated with enzyme-promoted rise in LBW might be ascribed to the influence of exogenous enzymes on nutrient digestion and utilization of dietary energy.

An increase in energy metabolizability and/or AME values in chickens fed cereal-based diets after supplementation with NSP-degrading carbohydrases was reported by Hew et al. (1998), Smulikowska ct al. (2000) and Szczurek et al. (2000a). This effect was evident with diets fortified with fat, saturated fat in particular, and correlated with enhanced weight gains of birds (Smulikowska and Mieczkowska, 1996; Koreleski et al., 2000). On the other hand, several recent studies with chickens clearly showed an increase in carcass fat, as well as growth rate, with increasing dietary energy levels (Yalçin et al., 1998; Dublecz et al., 1999).

Considering the findings cited above, it seems that the significant positive correlation between abdominal fat and relative rise in final body weight was obtained 
as a result of the higher metabolizable energy value of enzyme-supplemented diets, especially when preparations of xylanase or both xylanase and amylase activities were used. Part of this effect may be explained by better supplementary fat digestibility and absorption, or increased availability of fatty acids for deposition into adipose tissue, when ileal digesta viscosity is reduced by feed enzymes (Annison, 1995; Smulikowska, 1998).

\section{CONCLUSIONS}

The present results indicate that beneficial changes in broilers' weight gain due to enzyme supplementation of different fat-fortified cereal diets were accompanied by a rise in abdominal fat content. This relationship should be taken into account when formulating broiler feeds as attention should be paid to the adiposity of the birds. It may be suggested that in order to avoid augmented abdominal fat accumulation in chickens fed enzyme-supplemented cereal diets, the quantity of animal fats added to satisfy energy needs should be limited.

\section{REFERENCES}

Annison G., 1995. Feed enzymes - the science, future developments and practical aspects in feed formulation. In: Proceedings of $10^{\text {hs }}$ European Symposium on Poultry Nutrition, Antalya (Turkey). pp. 193-201

Bedford M.R., 2000. Enzymes for cereals which do not pose viscosity problems. In: Proceedings of $3^{\text {rs }}$ European Symposium on Feed Enzymes, Noordwijkerhout (The Netherlands), p. 18

Brenes A., Marquardt R.R., Guenter W., Rotter B.A., 1993. Effect of enzyme supplementation on the nutritional value of raw, autoclaved, and dehulled lupins (Lupinus albus) in chicken diets. Poultry Sci. 72, 2281-2293

Brufau J., Francesch M., Pérez-Vendrell A.M., 2001. NSP-degrading enzymes in poultry feeding. Recent developments and future prospects. In: Procecdings of $13^{\text {th }}$ European Symposium on Poultry Nutrition, Blankenberghe (Belgium), pp. 162-166

Dublecz K., Vineze I., Szüts G., Wágner L., Pál L., Bartos A., 1999. Effect of dietary energy level on the performance of broiler chicks. In: Procedings of $12^{\text {th }}$ European Symposium on Poultry Nutrition, Veldhoven (The Netherlands), pp. 424-426

European Table of Energy Values for Poultry Feedstuffs, 1989. $3^{\text {rd }}$ Edition. European Federation WPSA, Wageningen (The Netherlands)

Hew 1..1., Ravindran V., Mollah Y., Bryden W.L., 1998. Influence of exogenous xylanase supplementation on apparent metabolisable energy and amino acid digestibility in wheat for broiler chickens. Anim. Feed Sci. Tech. 75, 83-92

Koreleski J., Świątiewicz S., Hadula E., 2000. Effect of barley grain with different dietary starch and non-starch polysaccharide contents and of enzyme supplements on performance of broiler chickens (in Polish). Roc\%. Nauk. Zoot. - Ann. Anim. Sei. 27 (3), 161-178 
Lippens M., 2001. Influence of energy, protein, amino acids and management on breast meat and carcass fat. In: Proceedings of $13^{\text {th }}$ European Symposium on Poultry Nutrition, Blankenberghe (Belgium), pp. 1-8

Pack M.R., Bedford M.R., Coon C., Rostagno H., 1997. Effects of feed enzymes on ileal digestibility of energy and protein in corn-soybean diets fed to broilers. In: Proceedings of $11^{\text {th }}$ European Symposium on Poultry Nutrition, Faaborg (Denmark), pp. 502-504

Poultry Feeding Standards. Recommended Allowances and Nutritive Value of Feedstuffs (in Polish), 1996. S. Smulikowska (Editor). $3^{\text {rd }}$ Edition. The Kielanowski Institute of Animal Physiology and Nutrition, Polish Academy of Sciences. Jabłonna (Poland), pp. 45-50

Rosen G., 2000. Multi-factorial assesment of exogenous enzymes in broiler pronutrition: targets and problems. In: Proceedings of $3^{\text {rd }}$ European Symposium on Feed Enzymes, Noordwijkerhout (The Netherlands), p. 11

Simbaya J., Slominski B.A., Guenter W., Morgan A., Campbell L.D., 1996. The effect of protease and carbohydrase supplementation on nutritive value of canola meal for poultry: in vitro and in vivo studies. Anim. Feed Sci. Tech. 61, 219-234

Smith E.R., Pesti G.M., 1998. Influence of broiler strain cross and dietary protein on the performance of broilers. Poultry Sci. 77, 276-281

Smulikowska S., 1998. Relationship between the stage of digestive tract development in chicks and the effect of viscosity reducing enzymes on fat digestion. J. Anim. Feed Sci. 7, Suppl. 1, 125-135

Smulikowska S., Mieczkowska A., 1996. Effect of rye level, fat source and enzyme supplementation on fat utilization, diet metabolizable energy, intestinal viscosity and performance of broiler chickens. J. Anim. Feed Sci. 5, 379-393

Smulikowska S., Mieczkowska A., Nguyen V.C., 2000. Enzyme supplementation of wheat-based diet affects the ME-value of other dietary components depending on their fat content. In: Proceedings of $3^{\text {rd }}$ European Symposium on Feed Enzymes, Noordwijkerhout (The Netherlands), p. 80

Szczurek W., Koreleski J., 1998. Effect of different proportions of overheated double-low rapeseed meal and enzymatic supplements in feeds on rearing performance of broilers (in Polish). Rocz. Nauk. Zoot. 25 (3), 193-212

Szczurek W., Koreleski J., 1999. Effect of overheated meat meal dietary level and supplementation of enzymes on broiler chicks performance. Ann. Anim. Sci-Rocz. Nauk. Zoot. 26 (2), 119-132

Szczurek W., Koreleski J., Hanczakowski P., Szymczyk B., 2000a. The effects of enzyme supplements on protein utilization and energy metabolizability in broiler chickens fed a diet containing heat treated rapeseed meal as the main source of protein. Ann. Anim. Sci. - Rocz. Nauk. Zoot. 27 (4), 233-246

Szczurek W., Koreleski J., Świątkiewicz S., 2000b. Effect of reduced viscosity of intestinal contents on performance of broiler chickens (in Polish). Ann. Anim. Sci.-Rocz. Nauk. Zoot. 27 (1), 247264

Yalçin S., Özkan S., Açikgöz Z., Özkan K., 1998. Influence of dietary energy on bird performance, carcass part yields and nutrient composition of breast meat of heterozygous naked neck broilers reared at natural optimum and summer temperatures. Brit. Poultry Sci. 39, 633-638 


\section{STRESZCZENIE}

Wpływ zmian masy ciala i wskaźników wykorzystania paszy w następstwie stosowania dodatków enzymatycznych na podstawowe cechy poubojowe u kurcząt brojlerów żywionych mieszankami z dużym udzialem zbóż

Celem pracy było zbadanie w jakim stopniu wydajność rzeźna oraz udział tłuszczu brzusznego (sadełkowy + okołożołądkowy) w tuszce związane są ze zmianami masy ciała i różnicami w wykorzystaniu paszy przez kurczęta brojlery w następstwie stosowania enzymów paszowych w natłuszczanych mieszankach zbożowych.

Analizowano wyniki uzyskane łącznie w jedenastu doświadczeniach wzrostowych wykonanych na kurczętach z różnych linii, odchowywanych na ściółce ze słomy (7) lub w klatkach (4 doświadczenia). W doświadczeniach ptaki żywiono do woli sypkimi mieszankami paszowymi natłuszczanymi mieszaniną tłuszczów zwierzęcych. Głównymi składnikami stosowanych mieszanek były krajowe zboża i śruta sojowa. Enzymy paszowe (10 preparatów handlowych) wprowadzano do mieszanek oddzielnie lub łącząc preparaty o różnej aktywności.

Średnio we wszystkich doświadczeniach na wprowadzone dodatki enzymatyczne kurczęta zareagowały poprawą wskaźnika wykorzystania paszy (FCR) o $0,08 \mathrm{~g} / \mathrm{g}$, zwiększeniem końcowej masy ciała (LBW) o $86 \mathrm{~g}$, wydajności rzeźnej (CY) o 0,031\% i udziału tłuszczu brzusznego w tuszce (AF) o 0,024\%. Do obliczenia współczynników korelacji liniowej Pearsona i analizy regresji dane uzyskane w grupach doświadczalnych wyrażono w wartościach względnych, przyjmując odpowiednie wartości z grup kontrolnych (bez enzymów) za 1,00. Nie stwierdzono istotnych zależności między względnymi zmianami LBW i CY, FCR i CY, FCR i AF oraz CY i AF. Względne wartości AF były wysoce istotnie dodatnio skorelowane ze względnymi wartościami LBW. Zależność ta wyrażała się równaniem regresji liniowej: $\mathrm{Y}_{\mathrm{AF}}=-2.882+3.735 \mathrm{X}_{\mathrm{LBW}}\left(\mathrm{R}^{2}=0.529 ; \mathrm{P} \leq 0.001\right)$. Stwierdzona zależność wskazuje, że przy odchowie brojlerów otrzymujących natłuszczane mieszanki zbożowe uzupełniane enzymami rozkładającymi polisacharydy nieskrobiowe, zwiększonej masie ciała ptaków towarzyszy zwiększone otłuszczenie tuszek. Wskazuje to na konieczność ograniczenia zawartości tłuszczów zwierzęcych w takich mieszankach w celu zmniejszenia udziału thuszczu brzusznego w tuszkach kurcząt. 